\title{
Nesting behaviour of the Baya Weaver bird, Ploceus philippinus (Ploceidae) and the life-cycle of the Plains Cupid butterfly, Chilades pandava (Lycaenidae) with the red-listed Cycas sphaerica and C. beddomei (Cycadaceae)
}

\author{
A.J. Solomon Raju \\ Department of Environmental Sciences, Andhra University, Visakhapatnam, Andhra Pradesh 530003, India \\ Email: ajsraju@yahoo.com
}

Date of publication (online): 26 August 2009 Date of publication (print): 26 August 2009 ISSN $0974-7907$ (online) | 0974-7893 (print)

Editor: Cleo Cervanicia

\section{Manuscript details:}

Ms \# 02173

Received 13 February 2007

Final received 25 July 2009

Finally accepted 28 July 2009

Citation: Raju, A.J.S. (2009). Nesting behaviou of the Baya Weaver bird, Ploceus philippinus (Ploceidae) and the life-cycle of the Plains Cupid butterfly, Chilades pandava (Lycaenidae) with the red-listed Cycas sphaerica and $C$. beddome (Cycadaceae). Journal of Threatened Taxa 1(8) 429-433.

Copyright: (C A.J. Solomon Raju 2009. Creative Commons Attribution 3.0 Unported License. JoTT allows unrestricted use of this article in any medium for non-profit purposes, reproduction and distribution by providing adequate credit to the authors and the source of publication.

Author Details: Dr. A.J. Solomon RaJu is currently working as Associate Professor. $\mathrm{He}$ is presently working on endemic and endangered plant species in southern Eastern Ghats forests with financial support from DST, CSIR and UGC.

Acknowledgement: The work is an outcome of a research project funded by the Council of Scientific and Industrial Research, New Delhi.
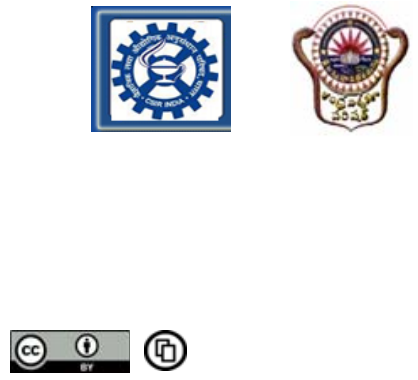

OPEN ACGESS | FREE DOWNLOAD
Abstract: The Baya Weaver bird, Ploceus philippinus utilizes the well developed leaves of Cycas sphaerica for nest construction and offspring production. It constructs nest on the leaf tips of this species; the nest material used is exclusively Dendrocalamus strictus. This bird species does not utilize Cycas beddomei for nest construction and offspring production. The Plains Cupid butterfly, Chilades pandava utilizes the newly emerging leaves of both $C$. sphaerica and $C$. beddomei for raising its offspring. In both the Cycas species, the new leaves emerge as a crown at the top of the plant; the larvae of $C$. pandava feed on these leaves and make the plant as leafless until the next leaf flushing season. New leaf production occurs after coning event in Cycas species; coning is not annual event. In consequence, the plants utilized by C. pandava for the production of its offspring remain leafless until the next coning season and their survival during this period depends on the nutrient status within the shoot system and in the soil system. The study suggests that there is no direct or indirect interaction between $C$. pandava and $P$. philippinus. C. sphaerica serves as a host plant for these two animal species at different times; but the interaction of these animal species is dependent on the leaves only; $C$. pandava on newly emerging leaves while $P$. philippinus on well developed leaves.

Keywords: Animal plant interaction, Chilades pandava, Cycas beddomei, Cycas sphaerica, Dendrocalamus strictus, Ploceus philippinus

\section{INTRODUCTION}

Cycas sphaerica Roxb. (Cycadaceae) occurs in dry forests and woodlands in the Eastern peninsular region of India on hills distributed from Chennai north to Bhubaneshwar; a population of more than 500 trees exists at Jalantrakota in the low elevation dry deciduous forest in Srikakulam District of Andhra Pradesh. This species falls under the Data Deficient category and is included in CITES Appendix II that allows trade in wild-cultivated seeds or plants as long as there is no detrimental impact on the survival of wild populations. C. beddomei Dyer is included in the IUCN Red list and is a Critically Endangered species restricted to the Seshachalam Hills of the Eastern Ghats in Andhra Pradesh (Hill et al. 2003; Reddy et al. 2006). There is no information on any aspect of C. sphaerica, and little information available on C. beddomei.

The Baya Weaver Bird, Ploceus philippinus is widespread and common within its distribution area but is prone to local, seasonal movement in search of nesting sites and food (BirdLife International 2008). It breeds during the monsoon period (Rasmussen $\&$ Anderton 2005). The occurrence and breeding of this bird in its distribution range are therefore related to the availability of nest sites and food resources. In this paper, the association and nesting behaviour of P. philippinus, and the association of life cycle of the Plains Cupid butterfly, Chilades pandava with C. sphaerica at Jalantrakota Reserve Forest and also with $C$. beddomei at Tirumala Hills is described based on field studies conducted at their natural sites. In C. sphaerica-P. philippinus association, it is found that the former is neither benefited nor harmed while the latter is benefited by using it as a nest host. In Cycas species-C. pandava association, the former are harmed by defoliation while the latter is benefited by using it as a host for raising its offspring.

\section{Materials and Methods}

Cycas sphaerica occurring at Jalantrakota Reserve Forest and C. beddomei at Tirumala Hills were used for the present study. The study was conducted during 2007-2008. The morphological characteristics were examined in the field. The sexual status of the plants was recorded when the plants flowered. The association of the Baya Weaverbird, Ploceus philippinus with C. sphaerica was carefully examined in the field. The nest materials 


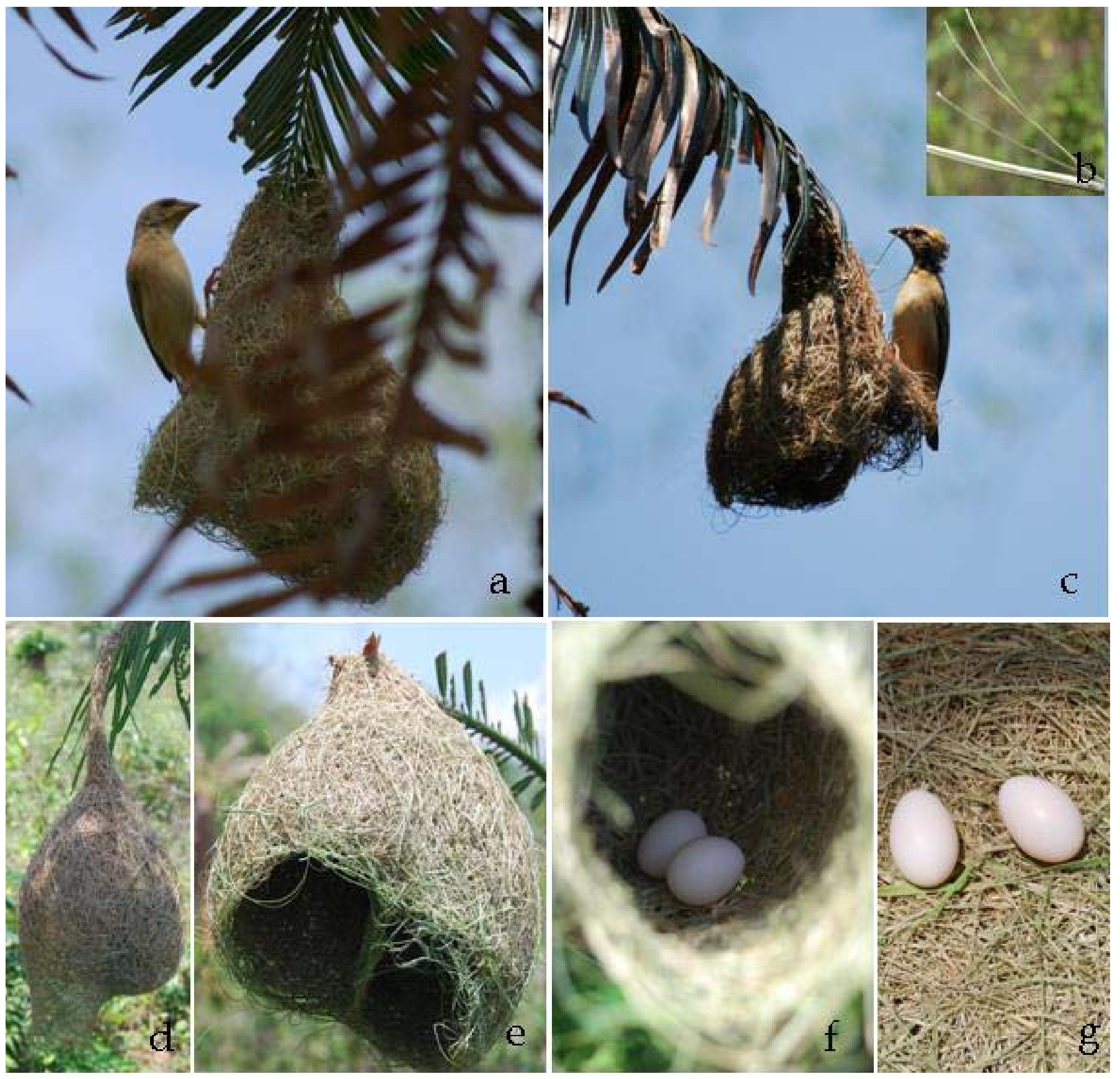

Image 1. Nest making by Ploceus philippinus on leaf tips of Cycas sphaerica

a - Female bird on the top of the nest; b - long strips removed from the culm of Dendrocalamus strictus; $\mathrm{c}$ - Breeding male bird weaving the nest; $d$ - Nest is almost completed and entrance tube is under construction; e - Roof and brood chamber of the nest; $f$ \& $g$ - Brood chamber with two eggs

used by the bird were recorded visually and also by using binoculars. The nest construction activity of the bird on the plant was observed by standing at the close quarters and by using binoculars; the entire length of the day was spent at the site for collecting accurate information. Seven days were used for this purpose. The nest structure was also examined and the details are noted. The association of the Plains Cupid butterfly, Chilades pandava with the newly emerging leaves of both the species of Cycas was examined in detail. The entire life cycle of the butterfly was observed during the study period.

\section{Observation}

Plant characteristics of Cycas species:

C. sphaerica is a medium-sized palm-like shrub with an erect solitary stem up to $2.36 \pm 1.4 \mathrm{~m}$ long (Range $1-5 \mathrm{~m}$ ) and $12-30$ $\mathrm{cm}$ diameter. Stem base is not strongly swollen and bark is thick with persistent leaf bases. The apex of the stem is crowned with 30-40 leaves; each leaf is $95-185 \mathrm{~cm}$ long. C. beddomei is a small palm-like shrub with an erect solitary stem up to $1.23 \pm 0.18 \mathrm{~m}$ long (Range $1-1.6 \mathrm{~m}$ ), often shorter, $15-20 \mathrm{~cm}$ diameter. The apex of the stem is crowned with 20-30 leaves; each leaf is $90.95 \pm 16.91 \mathrm{~cm}$ long (Range $75-135 \mathrm{~cm}$ ). Both $C$. 


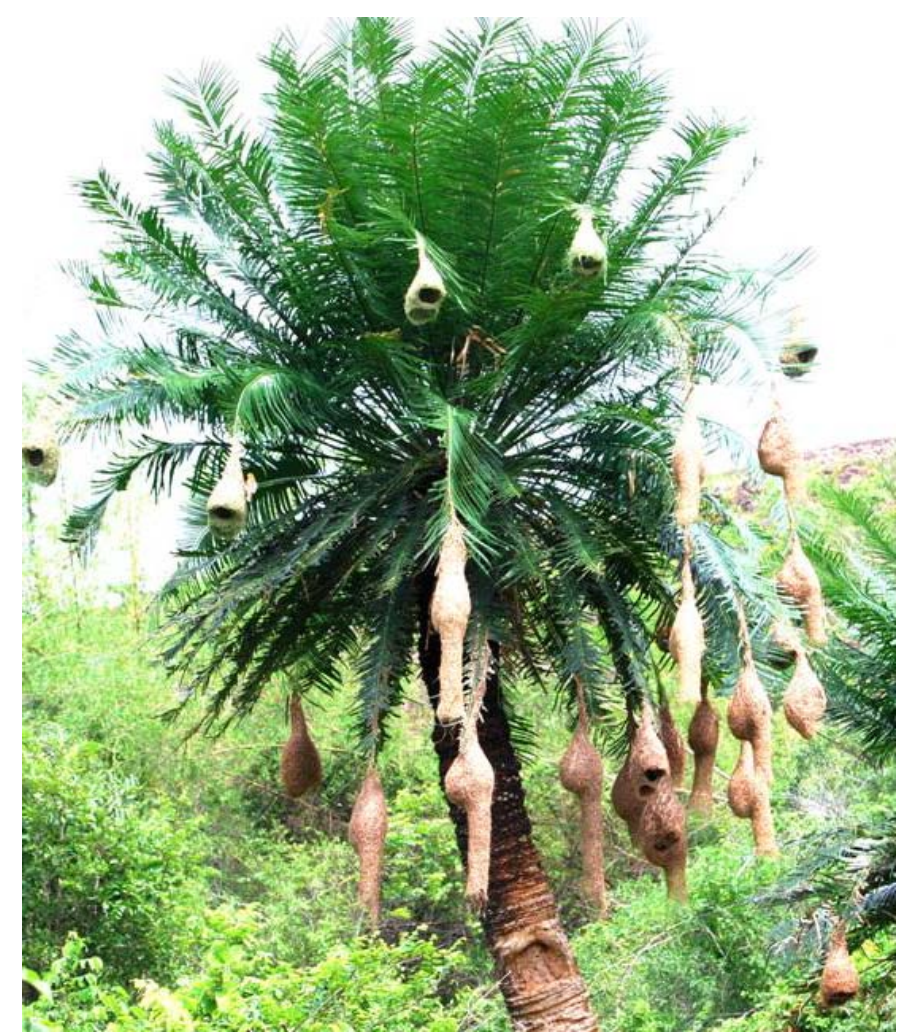

Image 2. Cycas sphaerica tipped with a number of completed and partially completed nests of Ploceus philippinus

sphaerica and C. beddomei are dioecious and the sex of each individual is identifiable only when male or female cones are formed.

\section{Association of Ploceus philippinus with C. sphaerica:}

Cycas sphaerica and Dendrocalamus strictus (Roxb.) Nees (Bambusaceae) are the most prominent species in the Jalantrakota Reserve Forest. The Baya Weaverbird, Ploceus philippinus L. constructs new nests on the leaf tips of $C$. sphaerica. Breeding males with a bright yellow crown, blackish-brown bill, upper parts dark brown streaked with yellow, with a yellow breast and cream buff below look different from breeding females. The male constructs the entire nest while female gives finishing touches to the nest if accepted by her (Borges et al. 2002). Both the sexes of the bird were found on C. sphaerica during nest construction phase (Image 1a,b). The males used their strong stout beaks to torn strips of 20-35 cm length from the culms of D. strictus (Image 1c); each strip was transported with the beak to the nest platform to weave and knot them while building their nests. They used only fresh, green strips of culms and grass blades to construct the nests. D. strictus being a bamboo, its fiber possesses excellent strength properties, especially tensile strength, which is required to withstand wear and tear of the extensively used components of the nest. Further, it is also known to possess silica particles in the epidermis layer of culm; these particles as very fine spicules give a definite interlocking between the interwoven fibers, thereby giving necessary stability to the stalk (Kumar et al. 1994; Borges et al. 2002). It is reported that the plant fibers free of silicious deposits are preferred for construction of the egg chamber to avoid discomfort to the altrical hatchlings (Borges et al. 2002). But, the weaver bird has been found to use almost exclusively $D$. strictus fiber for the construction of the entire nest, which may be due to non-availability of other materials in the area.

The Weaverbird's nest is unique for delicate craftsmanship of building intricate pendant nests. It has been reported that the bird uses Cocos nucifera, Eucalyptus sp., Careya arborea, Saccharum sp. and Bambusa sp. as nest building platforms (Borges et al. 2002). The criteria for the selection of such plants by the bird could be that their tall sturdy unbranched trunks and their crown of swaying fronds provide protection against intruders, lashing rains and violent winds, and provide a wider display surface for males to draw the attention of prospective female mates and withstand climatic vagaries (Davis 1974). But, the present study indicates that the bird uses C. sphaerica trees which are more than $3 \mathrm{~m}$ tall with a crown of leaves. This Cycas species provides the necessary protection as mentioned above for the nests of the weaver bird.

The nests observed are pendulous, hanging from the leaf tips; they are mono-storied, stalked, retort shaped, with a central nesting chamber and a long vertical tube that leads to a side entrance to the chamber (Venkataramani 1981). Sharma (1995) reported that this weaver bird rarely constructs stalk-less nests because such nests are hardly ever accepted by female birds. There are five stages in the construction of a nest: initial attachment, roof and egg/brood chamber, ante-chamber, entrance and entrance tube. The last stage is taken up by the male bird after the eggs have been laid by female bird. Two eggs per nest were observed; they are hard, pure white and stout in structure (Venkataramani 1981; Sharma 1995)(Image $1 \mathrm{~d}-\mathrm{g})$. There were some partially completed nests without any eggs on each tree that was used by the bird for nesting; these appear to be a result of non-acceptance of such nests by female bird (Image 2).

Wood (1926) mentioned that weaver birds, instead of building a nest once or twice a year, may repair old ones. At the study site, the males constructed all new nests. This is because leaf fall in C. sphaerica is an annual event and nests of the weaver bird fall to the ground along with the leaves. C. sphaerica being an ancient woody perennial seed plant, it is the sole plant that is available as nest building platform for P. philippinus in the Jalantrakota Reserve Forest. In C. sphaerica-P. philippinus association, the plant is not harmed or benefited while the bird is benefited by using the leaf tips of the plant as nest site. $C$. beddome $i$ is not suitable as a nest host plant for the weaver bird, for the reasons that the plant height is less and its leaves are situated near to the ground level.

\section{Association of Chilades pandava with C. sphaerica and C. beddomei:}

C. pandava utilizes C. sphaerica and C. beddomei for oviposition during summer season. In both the Cycas species, the new leaves emerge from the apex of the stem immediately after coning in both male and female trees. New leaf production is absent in trees that have not produced cones and such trees bear dry old leaves or remain leafless. The coning event and the number of coned trees in the population seem to indicate the prevalence of pest - C. pandava. It oviposits on the very young leaves which are still in curled up stage on coned trees (Image 3e,f). Eggs are very small, pale green colour (Image 3a), laid singly on newly emerging circinately coiled leaves before they are open and also on the tender leaves emerging from seedlings (Image $3 \mathrm{~g}$ ). Early instar larvae are purple (Image $3 \mathrm{~b}$ ) while 


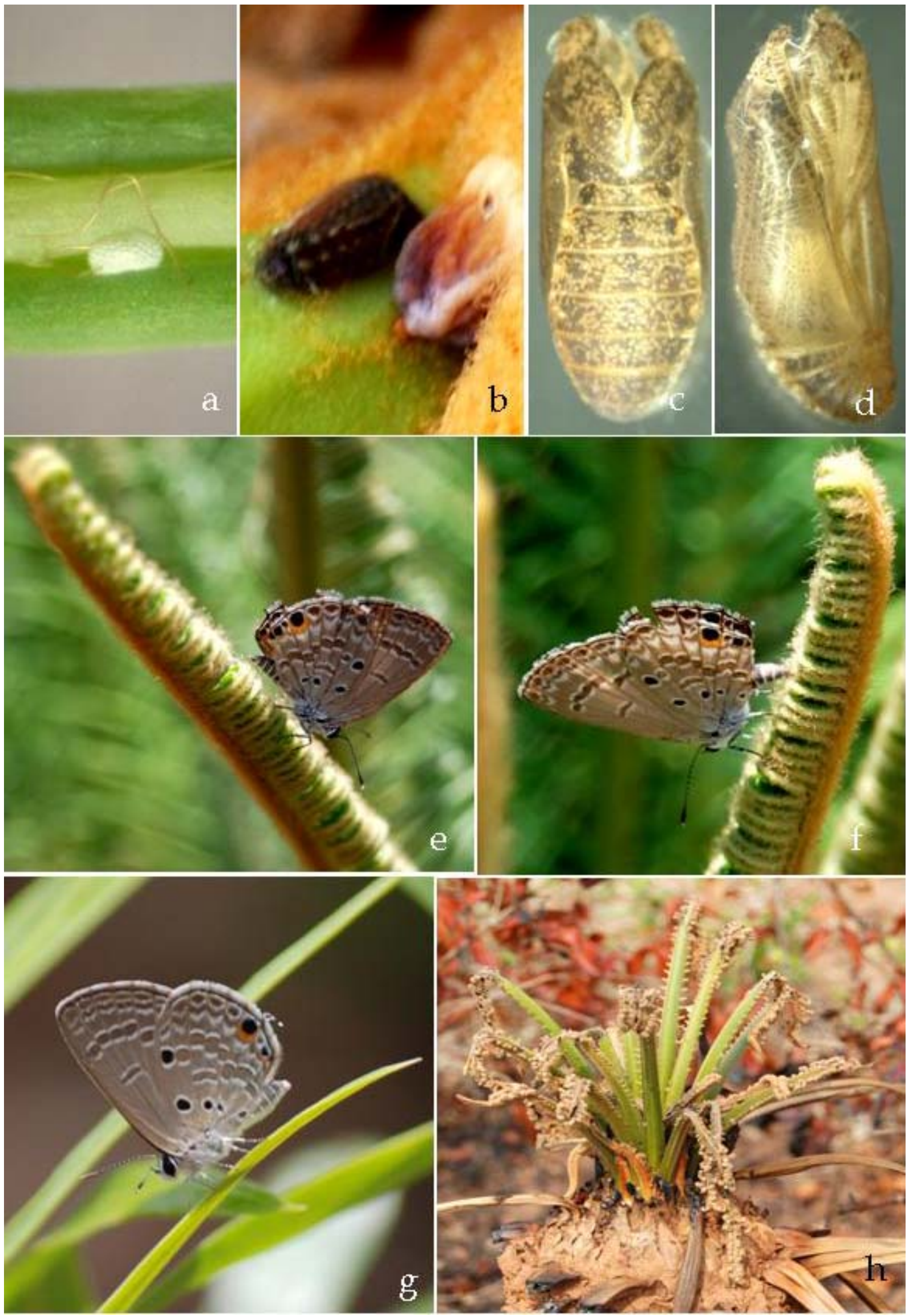

Image 3. Chilades pandava.

a-f - on Cycas beddomei. a - single egg deposition on the young leaf; b - larva; c \& d - pupa; e \& f - adult ovipositing on coiled leaflets. g-h - on Cycas sphaerica. g - adult about to oviposit on young leaf of seedling; $\mathrm{h}$ - state of coiled leaves after feeding by butterfly larvae. 
later larval instars are green. Pupa is grey coloured and human foot-shaped (Image 3c,d). The caterpillars feed only on new leaves before they harden but leave the rachis intact (Image $3 \mathrm{~h}$ ). In case of seedlings, the caterpillars feed on leaves and also bore young stem causing death of the seedlings. Damaged trees show wilting of leaf rachis without reemergence of new leaves in the same year and their survival depends on the nutrient environment within them and in the forest floor. Repeated defoliation on the same trees in successive years may lead to their mortality. A good population of this butterfly caterpillar could result in the complete defoliation of new leaves. Adults emerge within three weeks but they are not associated with Cycas trees for food purpose.

All cycads produce certain allelochemicals which are costly and risky for them but serve a protective function in evolution (Fraenkel 1959; Wink 1999). Cycasin is an important chemical produced in Cycas species; it is toxic to insects but the latter reduce the load by rapid excretion or detoxification or sequester as an acquired defensive substance. Cycad beetle, Rhopalotria bite off and eliminate trichomes from the surface of the cycad sporophyll before feeding, which may be because of its high toxin content (Norstog et al. 1992). The lycaenid butterfly, Eumaeus atala utilizes Cycads as larval host plant. Eggs are crowned by orange scales, detached from their mother's abdomen. These scales stick by their originally distal tips to the varnish of the egg-shell and are pulled out of their original sockets during oviposition. It is a case of egg protection by aposematism which is absent in C. pandava (Rothschild 1992). E. atala larvae store the ingested cycasin and transfer it to pupae and adults to avoid bird predators. The adults store $40 \%$ of their total cycasin in the wings where the birds try to seize for food. This is a case of aposematism which by definition is a secondary defense mechanism that warns potential predators of the existence of another primary defensive mechanism (Rothschild et al. 1986; Bowers \& Larin 1989; Bowers \& Farley 1990). Cycasin might force predators to combine sensing and memorizing unpalatability with eyespots (Nash et al. 1992; Ackery et al. 1993). C. pandava with eyespots on the margins of hind wings too might be using Cycas species as hosts to acquire cycasin to the levels required in adult wings to send warning signals to its predators so as to protect themselves from predation. In C. sphaerica, C. beddomei-C. pandava association, the plants are not benefited but harmed by the butterfly. The butterfly by feeding on the newly emerging leaves contributes to the failure of sexual reproduction due to non-availability of photosynthate and also affects the survival rate of both female and male trees as their natural habitat is rocky and characterized by nutrient-deficient soil environment. C. pandava is benefited by utilizing the plants for raising the offspring from egg to adult stage and by acquiring cycasin chemical for protection against its predators.

The study shows that there is no interaction between $C$. pandava and $P$. philippinus; the former utilizes the newly emerging leaves of C. sphaerica and C. beddomei while the latter utilizes well developed leaves of $C$. sphaerica for nest construction and for raising its offspring. There is no overlap of interactions of these two animal species with C. sphaerica. The new leaf production event in both Cycas species occurs after coning. The eggs of $C$. pandava hatch and produce Ist instar; subsequent larval instars emerge due to continuous feeding on the emerging leaves. Then, the larvae pupate and finally adults emerge. In this process, the entire crown of newly emerging leaves disappears and the plants become leafless until the next leaf flushing season. The plants which were not utilized by butterflies produce a crown of new leaves. $P$. philippinus utilizes leaf tips from such plants. Therefore, there is no direct or indirect interaction between $C$. pandava and $P$. philippinus. C. sphaerica serves as a host plant for these two animal species at different times; but the interaction of these animal species is dependent on the leaves only; $C$. pandava on newly emerging leaves while $P$. philippinus on well developed leaves.

\section{References}

Ackery, P.R., R.J. Nash, E.A. Bell \& K. Norstog (1993). Sequestration of MAM-glycosides in insects, pp. 3-7. In: Stevenson, D.W. \& K. Norstog (eds.). Proceedings.of the Second International Conference on Cycad Biology, Palm and Cycad Societies of Australia, Milton, Queensland

BirdLife International (2008). Ploceus philippinus. 2008 IUCN Red List of Threatened Species. IUCN 2008.

Borges, S.D., M. Desai \& A.B. Shanbhag (2002). Selection of nest platforms and the differential use of nest building fibres by the Baya weaver, Ploceus philippinus Linnaeus 1766. Tropical Zoology 15: 1725 .

Bowers, M.D. \& S. Farley (1990). The behaviour of grey jays, Perisoreus canadensis, towards palatable and unpalatable Lepidoptera. Animal Behaviour 39: 699-705.

Bowers, M.D. \& Z. Larin (1989). Acquired chemical defense in the Lycaenid butterfly, Eumaeus atala. Journal of Chemical Ecology 15: 1133-1146.

Davis, T.A. (1974). Selection of nesting trees and the frequency of nest visits by baya weaver bird. Journal of the Bombay Natural Historty Society 71: 356-366

Fraenkel, G. (1959). The raison d'etre of secondary plant substances. Science 129: 1466-1470.

Hill, K.D., C.J. Chen, \& P.K. Loc (2003). Regional Overview: Asia, pp. 25-30. In: Donaldson (ed.). Cycads: Status Survey and Conservation Action Plan. IUCN/SSC Cycad Specialist Group, IUCN-The World Conservation Union, Cambridge, UK.

Nash, R.J., E.A. Bell \& P.R. Ackery (1992). The protective role of cycasin in cycad-feeding Lepidoptera. Phytochemistry 31: 1955-1957.

Norstog, K.J., P.K.S. Fawcett \& A.P. Vovides (1992). Beetle pollination of two species of Zamia: evolutionary and ecological considerations. Palaeobotanist 41: 149-158.

Rasmussen, P.C. \& J.C. Anderton (2005). The Birds of South Asia. The Ripley Guide. Smithsonian Edition and Lynx Editions.

Rothschild, M. (1992). Egg protection by the atala hairstreak butterfly. Phytochemistry 31: 1959-1960.

Rothschild, M., R.J. Nash \& E.A. Bell (1986). Cycasin in the endangered butterfly Eumaeus atala Florida. Phytochemistry 25: 1853-1854.

Kumar, S., K.S. Shukla, I. Dev \& P.B. Dobriyal (1994). Bamboo preservation techniques: A Review. International Network for Bamboo and Rattan, Indian Council of Forestry Research Education, INBAR and ICFRE.

Sharma, S.K. (1995). A study of abnormal nests of Baya weaver bird Ploceus philippinus (Linn.) in Rajasthan. Journal of the Bombay Natural History Society 92: 67-76.

Reddy, C.S., K.N. Reddy, C. Pattanaik \& V.S. Raju (2006). Ethnobotanical Observations on some endemic plants of Eastern Ghats, India. Ethnobotanical leaflets 10: 82-91.

Venkataramani, K. (1981). Nests of Weaver birds on telegraph wires. NLBW 21: 18 .

Wink, M. (1999). Introduction, pp. 1-15. In: Functions of plant secondary metabolites and their exploitation in biotechnology (Annual Plant Reviews, Vol. 3), (ed.) M. Wink, Sheffield Academic Press, Sheffield, U.K.

Wood, A. (1926). The nest of the Baya Weaver bird. Auk XLIII: 295302

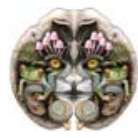

